\title{
Logistics of the Pass-through Route in the Multimodal Transportation (st. Astana- st. Dina Nurpeisova - Port Poti - Port Odessa - European Union)
}

\author{
Zhaken Kuanyshbayev \\ Faculty of Transport and Energy, L. N. Gumilyov Eurasian National University, Nur-Sultan, Kazakhstan
}

Email address:

lev-49-07@mail.ru

To cite this article:

Zhaken Kuanyshbayev. Logistics of the Pass-through Route in the Multimodal Transportation (st. Astana- st. Dina Nurpeisova - Port Poti - Port Odessa - European Union). American Journal of Applied Scientific Research. Special Issue: Transport and Transport Logistic.

Vol. 6, No. 2, 2020, pp. 49-60. doi: 10.11648/j.ajasr.20200602.15

Received: July 21, 2019; Accepted: December 16, 2019; Published: June 28, 2020

\begin{abstract}
The article presents the results of studies to determine the freight charge in the system of international freight transportation with the participation of the railways of the Republic of Kazakhstan, the Russian Federation, Azerbaijan, Georgia, Ukraine, Poland, as well as shipping through the Caspian Sea, Ukraine. The freight charge is determined when organizing container transportation. The calculations were performed both according to the methodology with a tariff fracture, and for the through-shoulder technique. The essence of the tariff fracture methodology is that when a freight train switches to the railway of a neighboring state, the transportation distance is reset. Carriage charges are calculated on the railway of a particular state from the border station to the next border station. Within the railway of the countries participating in international freight traffic, the freight charge is determined in national currency, then at the current rate it is converted into Swiss franc. It is known that the freight charge is determined on the basis of unit tariff rates and the corresponding differentiation scheme. There are three differentiation schemes in total. In all differentiation schemes, unit tariff rates depend on the distance of transportation. In these differentiation schemes, tariff rates decrease with increasing transportation distance. When using the through-shoulder technique, the tariff distance is determined from the departure station to the destination station, that is, according to the through-shoulder scheme. The freight charge is calculated in Swiss francs, which makes it possible to use the national currencies of the participating countries through the current exchange rate $C h F$. Since in this case the tariff distance according to the through-leverage scheme is greater than the tariff distances along the railways of the participating countries, the freight charge according to the through-leverage method will be less. This will reduce the freight charge for container transportation and offer railway customers more favorable conditions.
\end{abstract}

Keywords: Transportation, Route, Station, Tariff, Tariff Fracture, Through Shoulder

\section{Introduction}

Presented are the results of calculation of the charge based on the methodology with the tariff fracture and the method of the pass-through route. The scientific novelty of the article is to determine the charge based on the supranational currency EvroNur [1-3]. Between the EU and Asia-Pacific countries, about 6 million containers run annually. Now $98 \%$ of this flow is transported by a foreign sea fleet through foreign ports, bypassing the territory of Kazakhstan. At the same time, the transit route from the Asia-Pacific region to Europe via Kazakhstan is much shorter than the sea route. The main competitive advantage of Kazakhstan is a shorter, other things being equal, delivery time of goods. This circumstance allows us to predict the inevitable increase in freight flows in the direction of China - Europe and transit through Kazakhstan [4-7]. Today, developing countries, mainly Asian, produce about $60 \%$ of global GDP. Since now there is only one powerful Trans-Siberian railway passing through Russia to Europe, through which China and other Southeast Asian countries can transport goods, the PRC is interested in building a shorter and more efficient railway line. [8-14]. The new transport route will allow the transportation of 
goods not only from China, but also from all Southeast Asia through China and Kazakhstan to the West $[3-5,15,16]$. When organizing international rail transport one of the problematic issues is the determination of the freight charge. Since the freight train follows the railways of the countries of international freight traffic, the Swiss franc uses like supranational currency to determine the freight charge [7]. Then, the organization of electronic trading based on cryptocurrency PEERCOIN (PPC) is proposed [17].

It is known that the Single Transit Tariff [15] and the International Transit Tariff [18] are used in the system of the international freight transportation. The point of these tariffs is that the freight charge is determined on the basis of specific tariff rates, which depend on the distance of transportation. The amount of the freight charge is determined by the value of the tariff distance and the specific tariff rate. In order to obtain the freight charge in Swiss francs, the specific tariff rate is multiplied by the mass of the transported cargo. On the railways of the former Soviet Union, the freight charge was determined on the basis of the Rail-Atlas and Rail-Tarif software complex. In connection with the collapse of the Soviet Union and the formation of post-Soviet states, national currencies also appeared. And here there were problems determining the freight charge. There was a need to use a single currency within the Customs Union. The author of this article proposes a methodology for determining the freight charge according to the through-leverage scheme based on the supranational currency EuroNur. Below are the calculations for determining the freight charge according to the method with a tariff fracture and the through-leverage method. The freight train route runs along the railways of the Republic of
Kazakhstan, the Russian Federation, Azerbaijan, Georgia, the Black Sea, Ukraine, Poland (St. Kostrzyn). The freight charge is determined in the national currency of the countries participating in international freight traffic, then the freight charge is determined in Swiss francs. This makes it possible to determine the freight charge along the entire container train route. The sequence of calculations and the results of calculations by the method with a tariff fracture are shown in Table 2. Then, calculations were carried out to determine the freight charge by the through- leverage method (Table 4). The author of the scientific article proposes the supranational currency EuroNur (Table 5).

\section{Determination of Freight Charge According to the Method with a Tariff Fracture}

For example, the formation of the freight route by train during the transportation of grain (wheat), sending - carriage. For the carriage of the specified goods, choose a special rolling stock - grain carrier. The Republic of Kazakhstan produces about 20-25 million tons of grain every year, while for exporting from 8 to 10 million tons of grain. In this article, we will present the route and the definition of freight from Astana station (Kazakhstan) to the border station Kostrzyn (Poland). By rail of the Republic of Kazakhstan the route of the freight train follows from Astana station to the border station Dina Nurpeisova. Tariff distance is $2122 \mathrm{~km}$ (Figure 1).

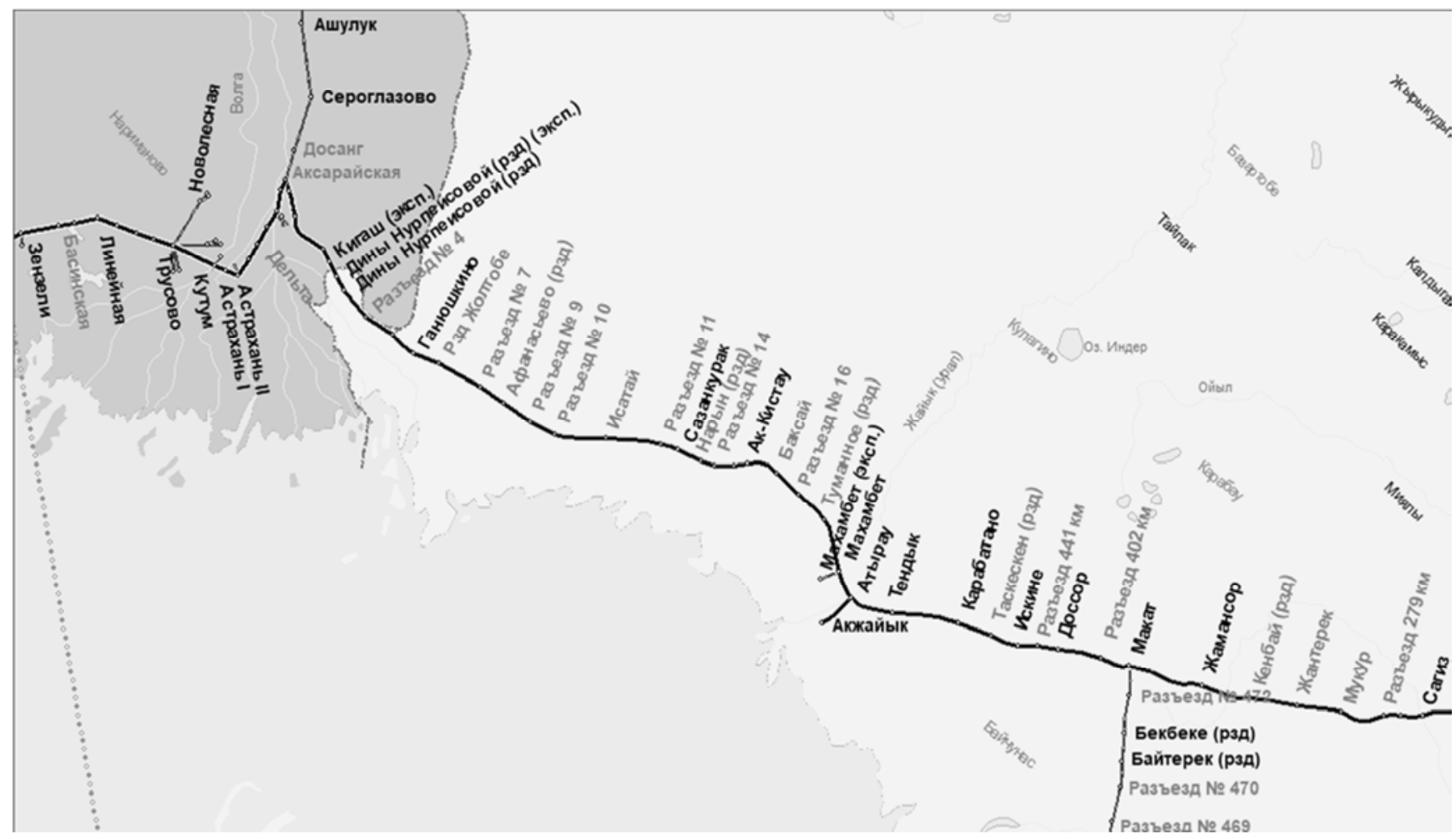

Figure 1. The route of the Kazakhstan's railways, border crossings. 
Calculations on the determination of the charge are presented in the national currency (tenge) and supranational currency, Swiss franc (Figures 2, 3).

\begin{tabular}{|c|c|c|c|c|c|c|c|c|c|c|c|c|c|}
\hline \multicolumn{3}{|c|}{ (Казахстанская ж. А.) } & \multicolumn{11}{|c|}{$\begin{array}{l}\text { (2) Санция назначения } 662407 \text { Дины Нурпеисовой (рзА) (Казахстанская Ж. А.) } \\
\text { - С Срана Казахстан } \\
\text { В Стоана назначения Казахстан }\end{array}$} \\
\hline Страна & Hanp. & Расстояние & ВИД & Пров. пл. & $\begin{array}{c}\text { 3а 1т } \\
\text { Пров. пл. }\end{array}$ & Охрана & Aon.c6оры & $\begin{array}{c}\text { Итoro } \\
\text { без НДC }\end{array}$ & ндС & Utoro & 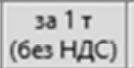 & 3a 1 т & Валюта \\
\hline \multirow{2}{*}{ Казахстан } & $\Rightarrow$ & 2122 & Пр. K3X & 184639,00 & 3077,32 & 0 & 0) & 184639,00 & 22156,68 & 206795,68 & 3077,32 & 3446,59 & KZT $\vee$ \\
\hline & $\leftarrow$ & 2122 & Пр. K3X & 78479,00 & 0 & 0 & 0 & 78479,00 & 9417,48 & 87896,48 & 0 & 0 & KZT $\backsim$ \\
\hline \multirow[t]{2}{*}{ Иroro } & & 4244 & & 263118,00 & 4385,30 & 0 & 0 & 263118,00 & 31574,16 & 294692,16 & 4385,30 & 4911,54 & KZT \\
\hline & & 4244 & & 263118,00 & 4385,30 & 0 & 0 & 263118,00 & 31574,16 & 294692,16 & 4385,30 & 4911,54 & KZT \\
\hline
\end{tabular}

Figure 2. Definition of a freight charge along the route st. Astana-st. Dina Nurpeisova, tenge.

\begin{tabular}{|c|c|c|c|c|c|c|c|c|c|c|c|c|c|}
\hline Страна & Hanp. & Расстояние & ВИД & Пров. пл. & $\begin{array}{c}\text { за 1т } \\
\text { Пров. пл. }\end{array}$ & Охрана & Aon.c6оры & $\begin{array}{c}\text { Итoro } \\
\text { 6ез НДС }\end{array}$ & НдС & Итoro & $\begin{array}{c}\text { sa } 1 \mathrm{~T} \\
(6 е з \mathrm{HAC})\end{array}$ & за $1 \mathrm{~T}$ & Валюта \\
\hline \multirow{2}{*}{ Қазахстан } & $\Rightarrow$ & 2122 & Пр. KBX & 541,88 & 9,03 & 0 & 0 & 541,88 & 65,03 & 606,91 & 9,03 & 10,12 & CHF \\
\hline & $\leftarrow$ & 2122 & Пр. K3X & 230,32 & 0 & 0 & 0 & 230,32 & 27,64 & 257,96 & 0 & 0 & $\mathrm{CHF}$ \\
\hline \multirow[t]{2}{*}{ Uroro } & & 4244 & & 772,20 & 12,87 & 0 & 0 & 772,20 & 92,67 & 864,87 & 12,87 & 14,41 & $\mathrm{CHF}$ \\
\hline & & 4244 & & 772,20 & 12,87 & 0 & 0 & 772,20 & 92,67 & 864,87 & 12,87 & 14,41 & CHF \\
\hline
\end{tabular}

Figure 3. Determination of the freight charge along the route st. Astana - st. Dina Nurpeisova, Swiss franc.

\subsection{Determination of Freight Charge According to the Method with a Tariff Fracture on Kazakhstan}

The route of the freight train on the railways of the Russian Federation follows from the Kigash station - to the station Samur-exp., (Figure 4). Tariff distance is $748 \mathrm{~km}$. Freight charge is defined in the national currency of the Russian Federation (ruble) and supranational currency (Figures 5, 6).

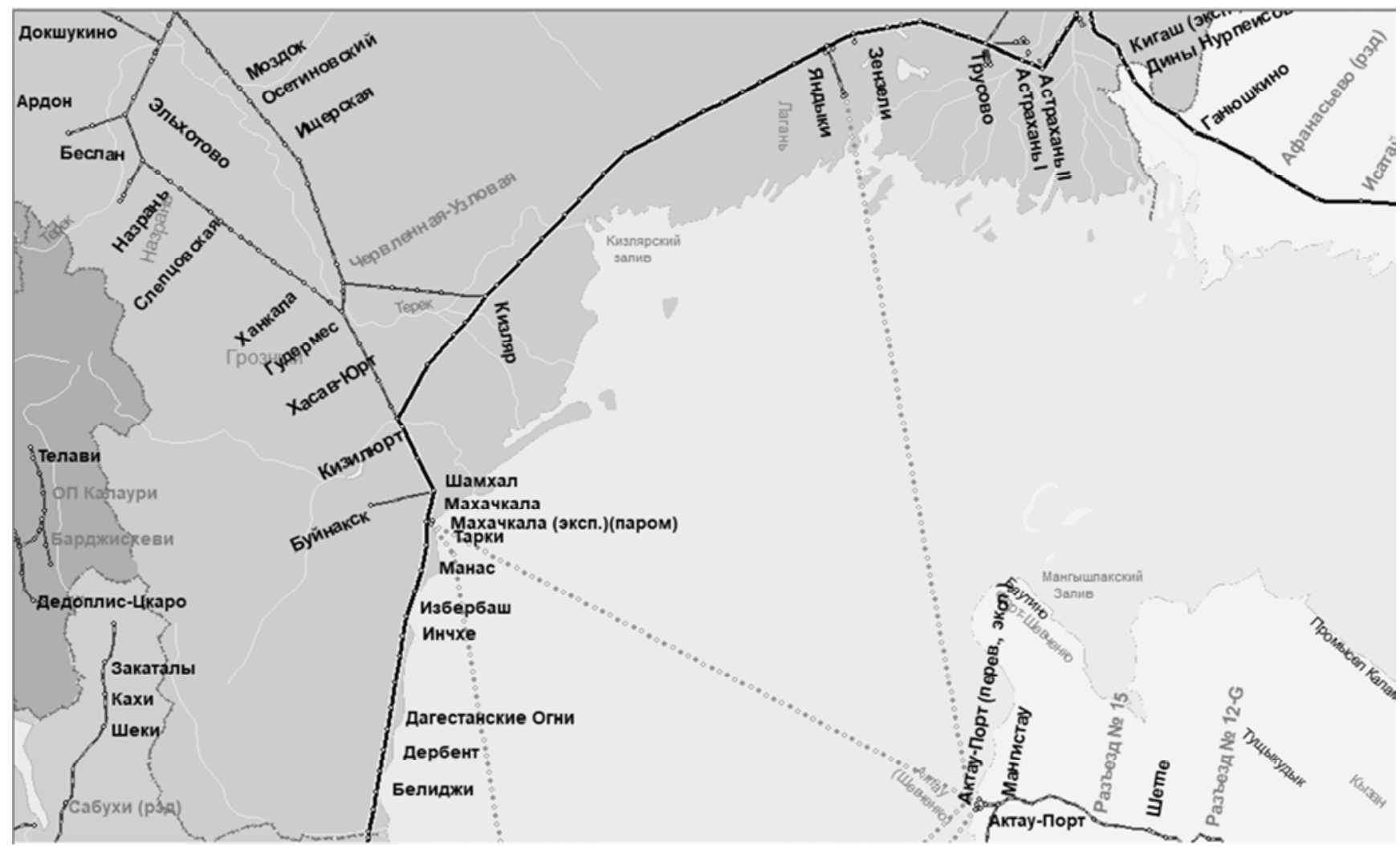

Figure 4. The route of the Russian Federation's railways, border crossings. 
2.2. Determination of Freight Charge According to the Method with a Tariff Fracture on Russian

\begin{tabular}{|c|c|c|c|c|c|c|c|c|c|c|c|c|c|c|}
\hline Страна & Hanp. & Расстояние & Вид & Пров. пл. & $\begin{array}{c}\text { за 1т } \\
\text { Пров. пл. }\end{array}$ & Охрана & Aon.c6оры & $\begin{array}{l}\text { Итoro } \\
\text { 6ез НДС }\end{array}$ & НдС & Utoro & $\begin{array}{c}3 а 1 \mathrm{~T} \\
(6 е з \mathrm{H} Д \mathrm{C})\end{array}$ & 3a $1 \mathrm{~T}$ & Валюта & \\
\hline \multirow{2}{*}{ Россия } & $\Rightarrow$ & 748 (TP4 748) & $\mathrm{T} \cap \mathrm{CH}$ & 91713,66 & 1528,56 & 口 & 503,76 & 92217,42 & 0 & 92217,42 & 1536,96 & 1536,96 & RUB & $\checkmark$ \\
\hline & $\leftarrow$ & 748 (TP4 748) & $\mathrm{T} \Pi \mathrm{CHI}$ & 18471,14 & 0 & 0 & 0 & 18471,14 & 3324,81 & 21795,95 & 0 & 0 & RUB & $\checkmark$ \\
\hline \multirow[t]{2}{*}{ Utoro } & & 1496 & & 110184,80 & 1836,41 & 0 & 503,76 & 110688,56 & 3324,81 & 114013,37 & 1844,81 & 1900,22 & RUB & \\
\hline & & 1496 & & 110184,80 & 1836,41 & 0 & 503,76 & 110688,56 & 3324,81 & 114013,37 & 1844,81 & 1900,22 & RUB & \\
\hline
\end{tabular}

Figure 5. Determination of the charge for the route along the route Kigash (exp.), - Samur (exp.), Russia.

\begin{tabular}{|c|c|c|c|c|c|c|c|c|c|c|c|c|c|}
\hline Страна & Hanp. & Расстояние & ВИд & Пров. пл. & $\begin{array}{c}\text { за 1т } \\
\text { Пров. пл. }\end{array}$ & Охрана & Aon.c6оры & $\begin{array}{c}\text { Иroro } \\
\text { 6ез HAC }\end{array}$ & НДС & Итого & $\begin{array}{c}\text { за } 1 \mathrm{~T} \\
(6 \mathrm{ez} \mathrm{H} Д \mathrm{C})\end{array}$ & 3а $1 \mathrm{\tau}$ & Валюта \\
\hline \multirow{2}{*}{ Россия } & $\Rightarrow$ & 748 (TP4 748) & $\mathrm{T} \cap \mathrm{CH \Gamma}$ & 1485,60 & 24,76 & 口 & 8,16 & 1493,76 & 0) & 1493,76 & 24,90 & 24,90 & CHF $\vee$ \\
\hline & 4 & 748 (TP4 748) & $\mathrm{T \Pi} \mathrm{CH \Gamma}$ & 299,20 & 0 & 0 & 0 & 299,20 & 53,86 & 353,06 & 0 & 0 & CHF $\vee$ \\
\hline \multirow[t]{2}{*}{ Uroro } & & 1496 & & 1784,80 & 29,75 & 0 & 8,16 & 1792,96 & 53,86 & 1846,82 & 29,88 & 30,78 & $\mathrm{CHF}$ \\
\hline & & 1496 & & 1784,80 & 29,75 & 0 & 8,16 & 1792,96 & 53,86 & 1846,82 & 29,88 & 30,78 & $\mathrm{CHF}$ \\
\hline
\end{tabular}

Figure 6. Determination of the charge for the route along the route Kigash (exp.), - Samur (exp.), Russia, Swiss franc.

The route of the freight train on the railways of the Republic of Azerbaijan follows from the station Yalama-exp. to station Boyuk-Kasik-exp. (Figures 7, 8). Tariff distance by rail of the Republic of Azerbaijan is 680km. Freight charge is defined in the national currency of the Republic of Azerbaijan (manat) and supranational currency (Figures 9, 10, 11).

\subsection{Determination of Freight Charge According to the Method with a Tariff Fracture on Azerbaijan}

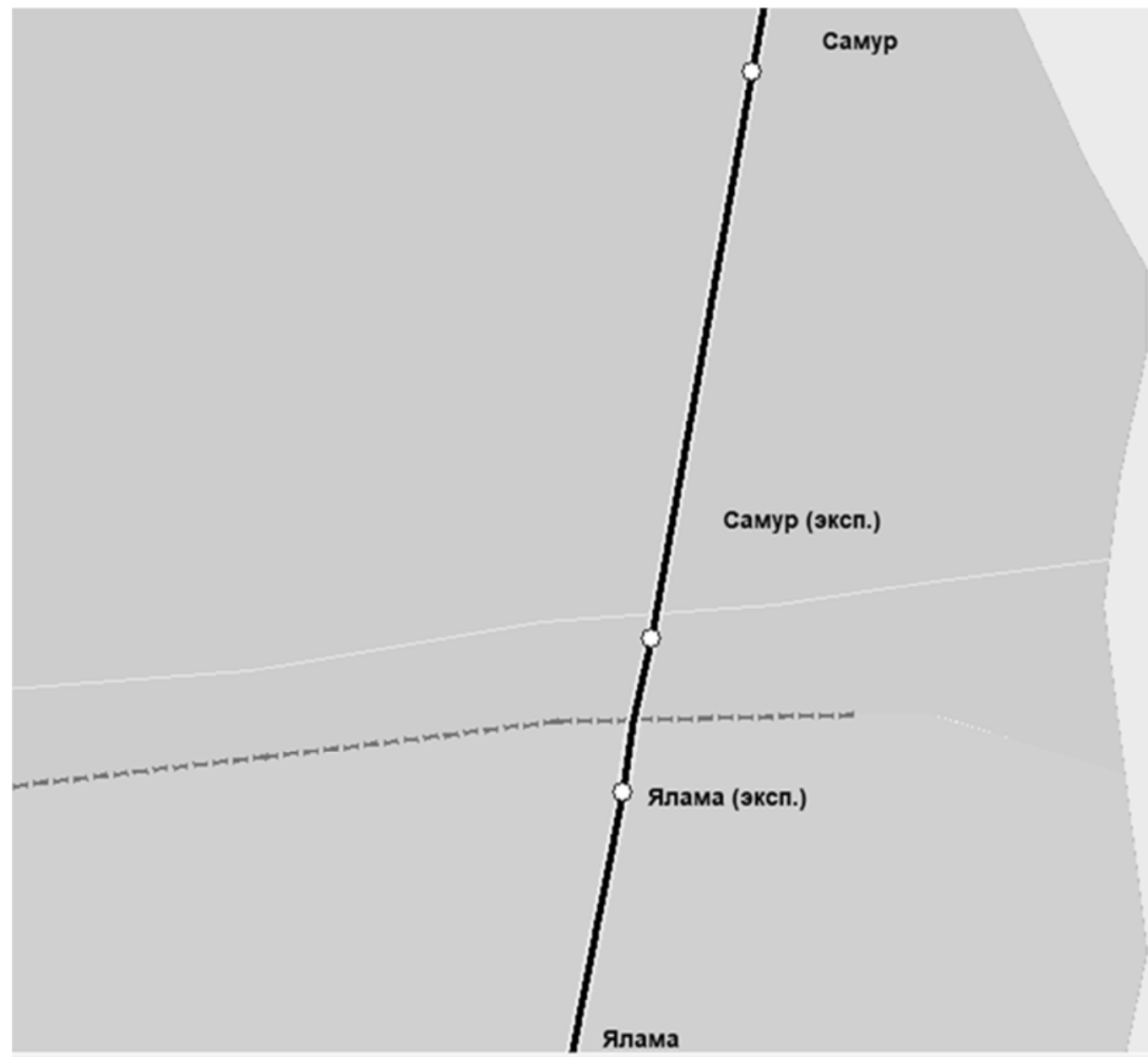

Figure 7. Border crossing Samur (exp.), RZD-Yamala (exp.), Azerbaijan. 


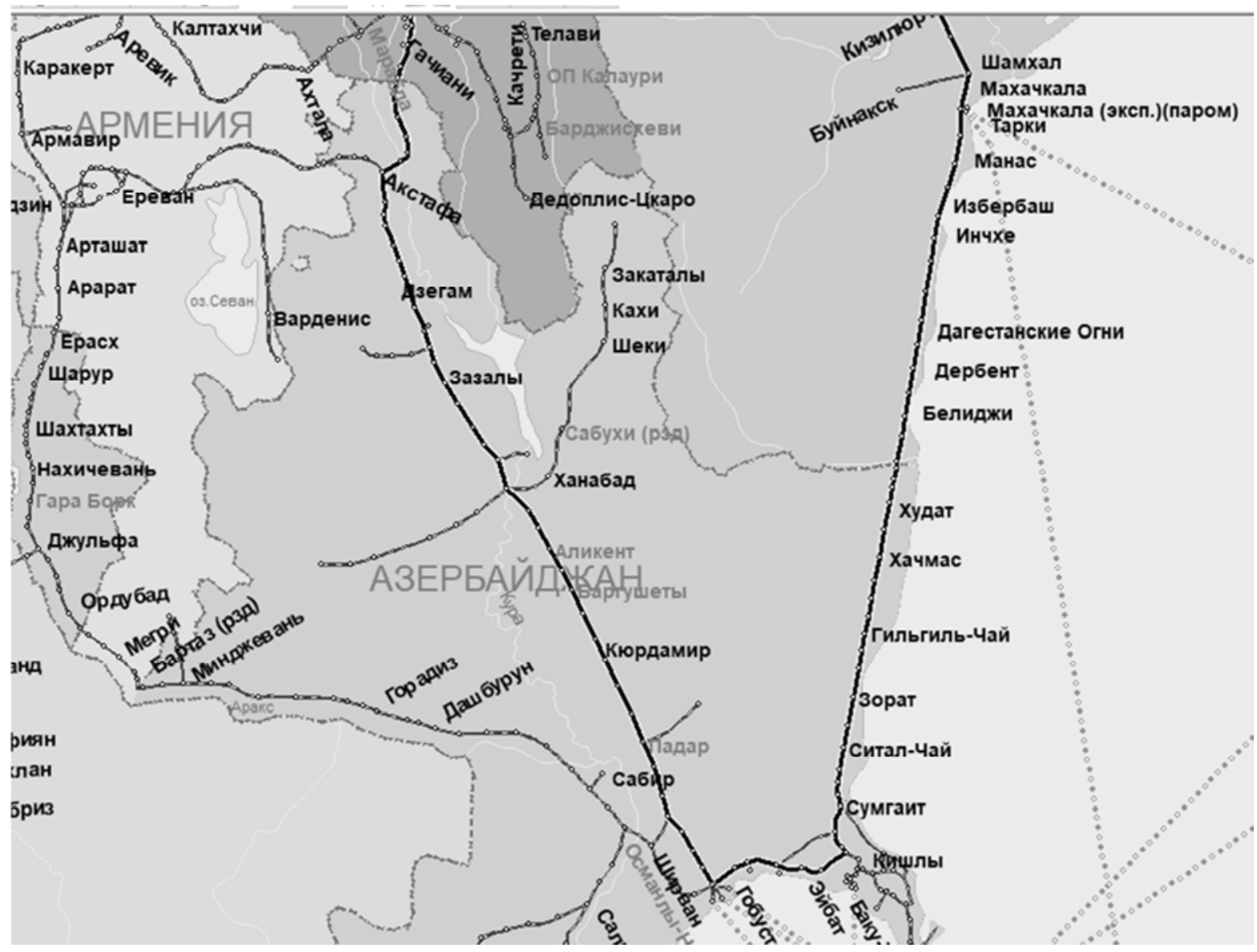

Figure 8. The route of Azerbaijan Republic's railways st. Yalama (exp.) - Boyuk Kesik (exp.).

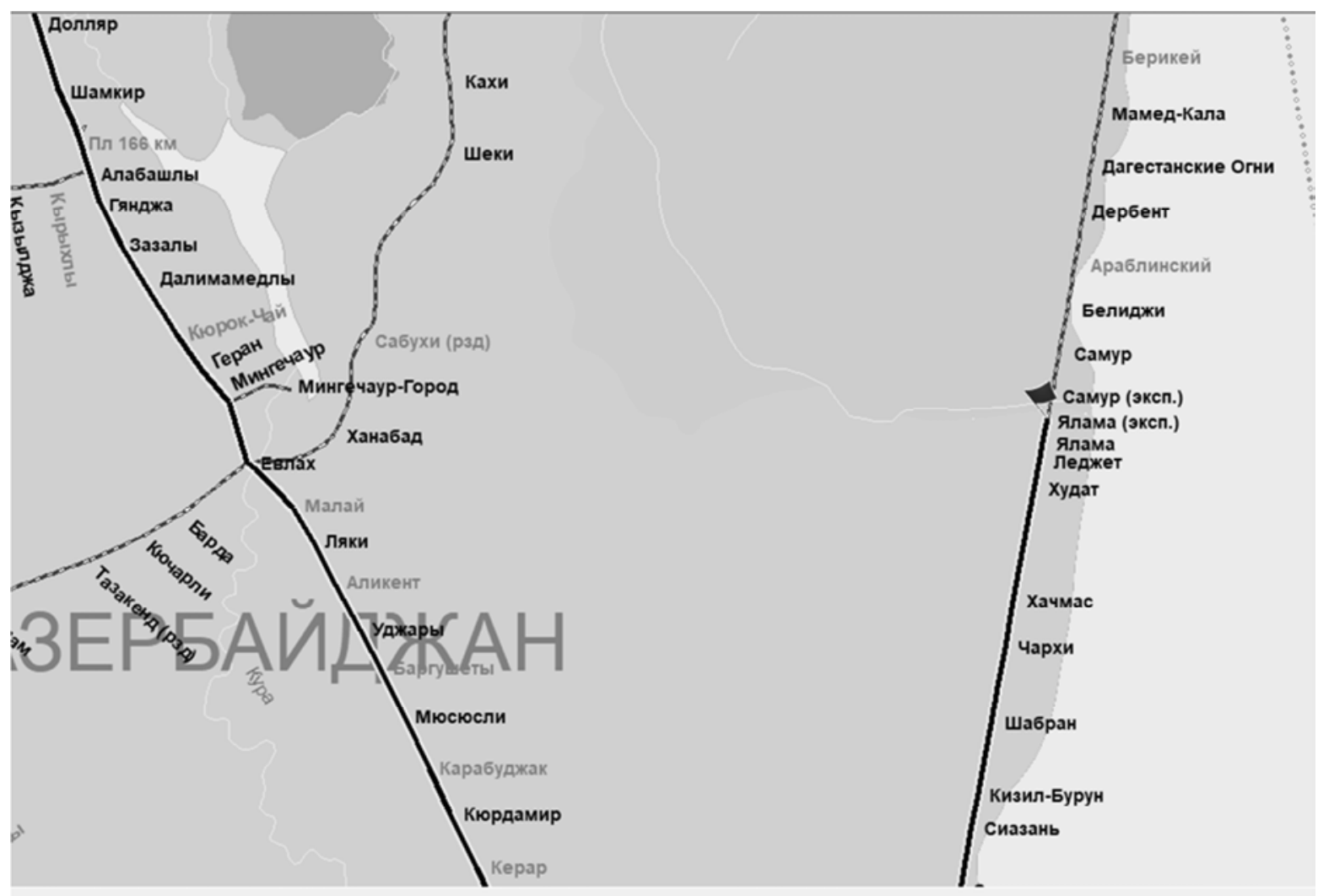

Figure 9. Yalama border station (exp.), Azerbaijan. 


\begin{tabular}{|c|c|c|c|c|c|c|c|c|c|c|c|c|c|}
\hline Страна & Hanp. & Расстояние & вид & Пров. пл. & $\begin{array}{c}\text { за 1т } \\
\text { Пров. пл. }\end{array}$ & Охрана & Доп.c6оры & $\begin{array}{c}\text { Итого } \\
6 \mathrm{ez} \text { HAC }\end{array}$ & НДС & Итого & $\begin{array}{c}\text { за } 1 \mathrm{~T} \\
(6 \mathrm{e} 3 \mathrm{HAC})\end{array}$ & за 1 т & Валюта \\
\hline \multirow{2}{*}{ Азербайджан } & $\Rightarrow$ & 680 (TP4 680) & ТП СНГ & 2576,57 & 42,94 & 口 & 14,45 & 2591,02 & 0 & 2591,02 & 43,18 & 43,18 & AZN $\checkmark$ \\
\hline & $\leftarrow$ & 680 (TP4 680) & $\mathrm{T} \Pi \mathrm{CH \Gamma}$ & 481,66 & 0 & 0 & 0 & 481,66 & 0 & 481,66 & 0 & 0 & AZN $\checkmark$ \\
\hline \multirow[t]{2}{*}{ Иioro } & & 1360 & & 3058,23 & 50,97 & 0 & 14,45 & 3072,68 & 0 & 3072,68 & 51,21 & 51,21 & $A Z N$ \\
\hline & & 1360 & & 3058,23 & 50,97 & 0 & 14,45 & 3072,68 & 0 & 3072,68 & 51,21 & 51,21 & AZN \\
\hline
\end{tabular}

Figure 10. Determination of the charge for the route along the route of Yalama station (exp.), - Boyuk-Kesik (exp.), Azerbaijan, Azerbaijan manat.

\begin{tabular}{|c|c|c|c|c|c|c|c|c|c|c|c|c|c|}
\hline Страна & Hanp. & Расстояние & вИд & Пров. пл. & $\begin{array}{c}\text { за 1т } \\
\text { Пров. пл. }\end{array}$ & Охрана & Доп.сборы & $\begin{array}{c}\text { Итoro } \\
6 \mathrm{ez} \mathrm{HДC}\end{array}$ & $\mathrm{HAC}$ & Итого & $\begin{array}{c}\text { 3а } 1 \mathrm{\tau} \\
(6 е з \mathrm{H} Д \mathrm{C})\end{array}$ & 3a $1 \mathrm{~T}$ & Валюта \\
\hline \multirow{2}{*}{ Азербайджан } & $\Rightarrow$ & 680 (TP4 680) & $\mathrm{T} \Pi \mathrm{CH}$ & 1455,00 & 24,25 & 口 & 8,16 & 1463,16 & 0 & 1463,16 & 24,39 & 24,39 & CHF $V$ \\
\hline & $\leftarrow$ & 680 (TP4 680) & $\mathrm{T} \Pi \mathrm{CH \Gamma}$ & 272,00 & 0 & 0 & 0 & 272,00 & 0 & 272,00 & 0 & 0 & $\mathrm{CHF} \checkmark$ \\
\hline \multirow[t]{2}{*}{ Итого } & & 1360 & & 1727,00 & 28,78 & 0 & 8,16 & 1735,16 & 0 & 1735,16 & 28,92 & 28,92 & $\mathrm{CHF}$ \\
\hline & & 1360 & & 1727,00 & 28,78 & 0 & 8,16 & 1735,16 & 0 & 1735,16 & 28,92 & 28,92 & CHF \\
\hline
\end{tabular}

Figure 11. Determination of the charge for the route along the route of Yalama station (exp.), - Boyuk-Kesik (exp.), Azerbaijan, Swiss franc.

\subsection{Determination of Freight Charge According to the Method with a Tariff Fracture on Georgia}

The route of the freight train on the railways of the Republic of Georgia follows from the station Gardebani - to the station, the port of the same name Poti (Figures 12,13). Tariff distance by rail of the Republic of Georgia is 360km. Freight charge is defined in dollars and supranational currency (Figures 14, 15).

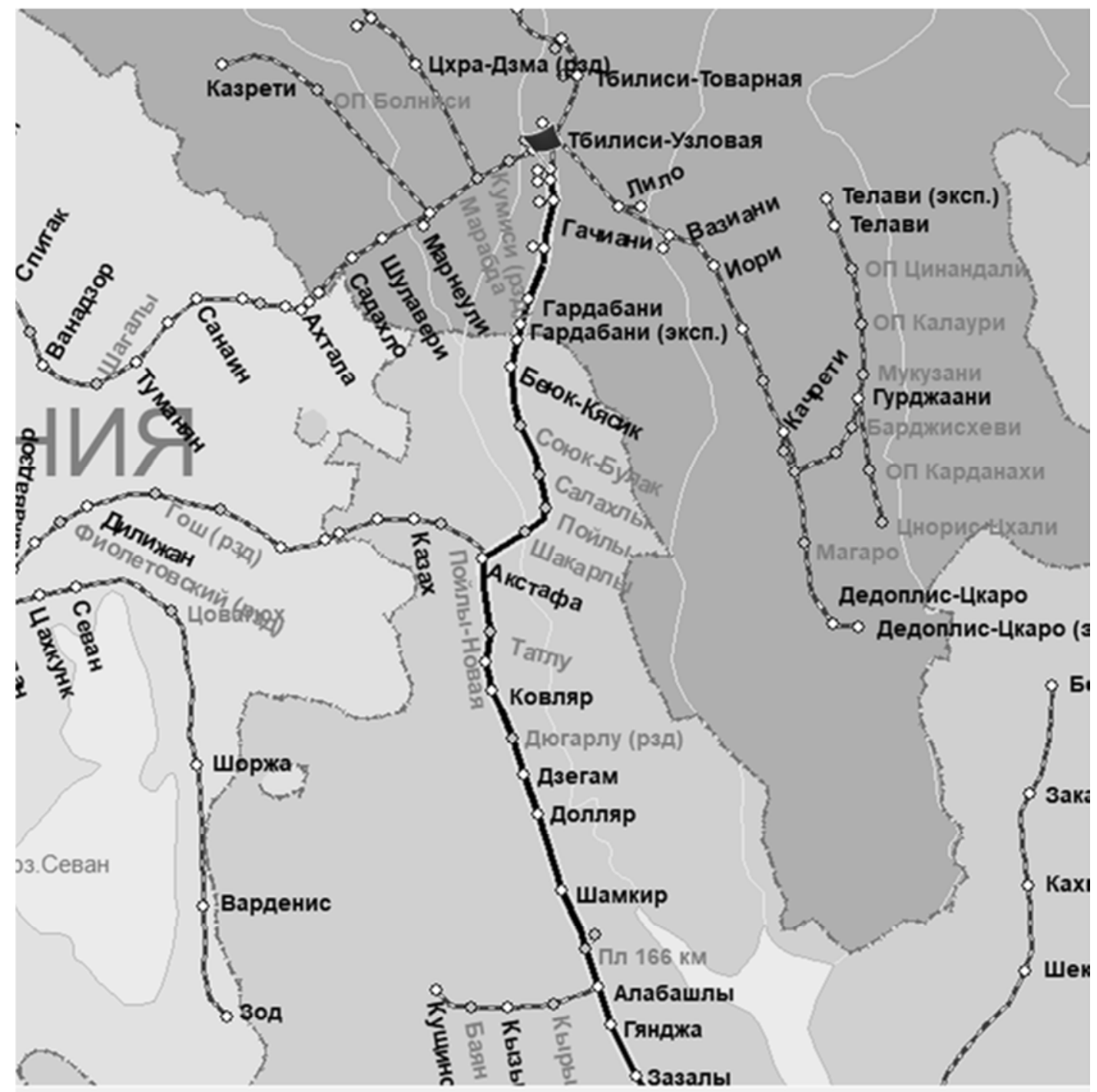

Figure 12. The route of Georgia's railways, through the border crossing st. Boyuk Kesik-st. Gardebani (exp.). 


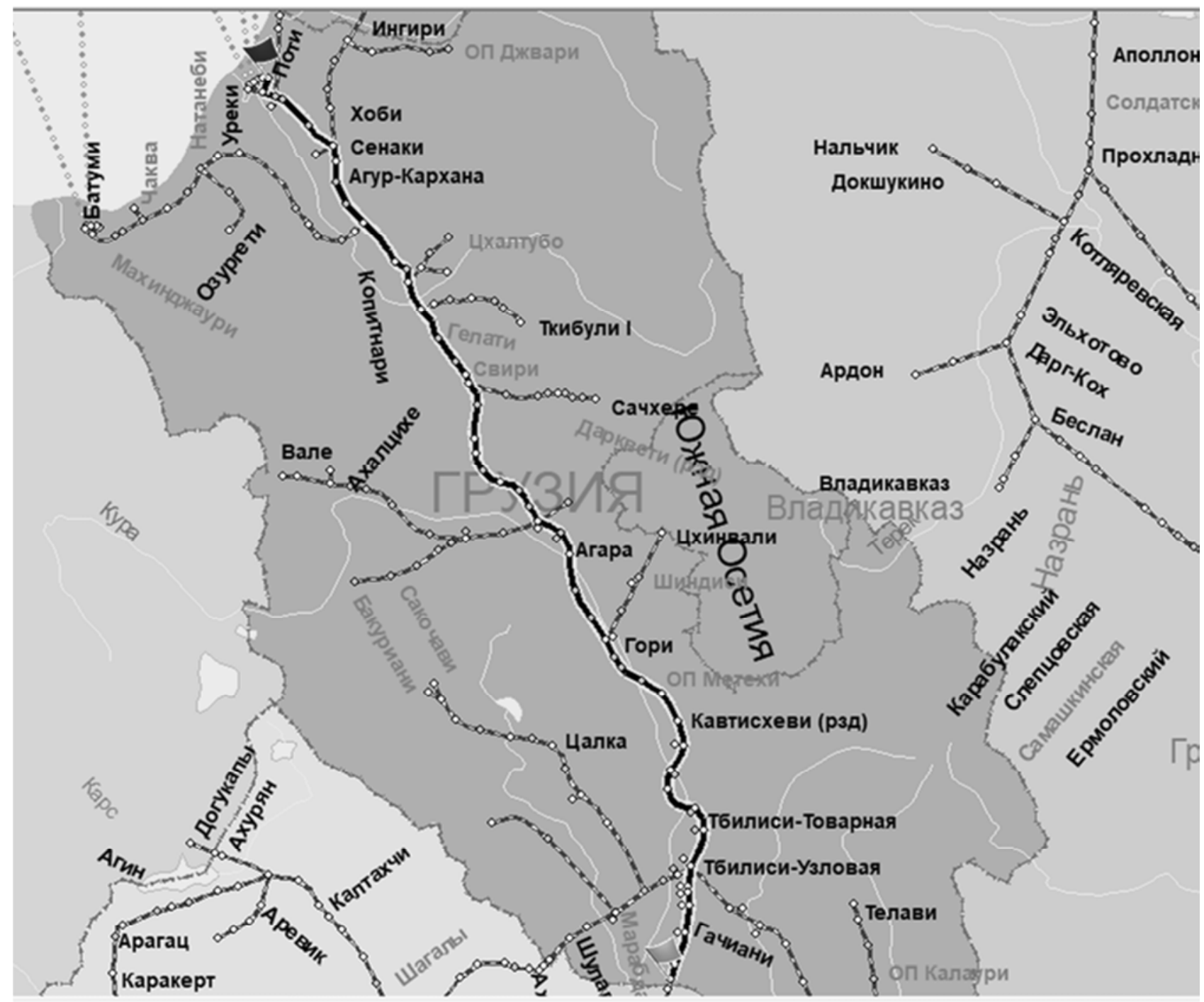

Figure 13. The route of Georgia's railways st. Gardabani - st. Poti.

\begin{tabular}{|c|c|c|c|c|c|c|c|c|c|c|c|c|c|c|}
\hline Страна & Hanp. & Расстояние & вид & Пров. пл. & \begin{tabular}{|c|} 
за 1т \\
Пров. пл.
\end{tabular} & Охрана & Aоn.с6оры & $\begin{array}{c}\text { Итoro } \\
6 \mathrm{e} 3 \mathrm{HAC}\end{array}$ & НДС & Итoro & $\begin{array}{c}3 \mathrm{a} 1 \mathrm{~T} \\
(6 \mathrm{es} \mathrm{HAC})\end{array}$ & 3a $1 \mathrm{~T}$ & Валют & \\
\hline \multirow{2}{*}{ Грузия } & $\Rightarrow$ & 360 (TP4 362) & $\Gamma P$ & 690,00 & 11,50 & 0 & 113,50 & 803,50 & 0 & 803,50 & 13,39 & 13,39 & USD & $\checkmark$ \\
\hline & $\leftarrow$ & 360 (TP4 362) & $\Gamma P$ & 169,92 & 0 & 0 & 16,48 & 186,40 & 0 & 186,40 & 0 & 0 & USD & $\checkmark$ \\
\hline \multirow[t]{2}{*}{ Иroro } & & 720 & & 859,92 & 14,33 & 0 & 129,98 & 989,90 & 0 & 989,90 & 16,50 & 16,50 & USU & \\
\hline & & 720 & & 859,92 & 14,33 & 0 & 129,98 & 989,90 & 0 & 989,90 & 16,50 & 16,50 & USD & \\
\hline
\end{tabular}

Figure 14. The transportation charge on the route of Gardebani station (exp.) - the port of Poti, the Republic of Georgia, the US dollar.

\begin{tabular}{|c|c|c|c|c|c|c|c|c|c|c|c|c|c|}
\hline Страна & Hanp. & Расстояние & ВИд & Пров. пл. & $\begin{array}{c}\text { за 1т } \\
\text { Пров. пл. }\end{array}$ & Охрана & Дon.c6оры & $\begin{array}{c}\text { Итoro } \\
\text { 6ез НДС }\end{array}$ & НДС & Итoro & 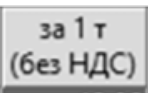 & 3a $1 \mathrm{~T}$ & Валюта \\
\hline \multirow{2}{*}{ Грузия } & $\Rightarrow$ & 360 (TP4 362) & $\Gamma P$ & 662,40 & 11,04 & 0 & 108,96 & 771,36 & 0 & 771,36 & 12,86 & 12,86 & CHF \\
\hline & $\leftarrow$ & 360 (TP4 362) & ГP & 163,12 & 0 & 0 & 15,82 & 178,94 & 0 & 178,94 & 0 & 0 & $\mathrm{CHF}$ \\
\hline \multirow[t]{2}{*}{ Uroro } & & 720 & & 825,52 & 13,76 & 0 & 124,78 & 950,30 & 0 & 950,30 & 15,84 & 15,84 & $\mathrm{CHF}$ \\
\hline & & 720 & & 825,52 & 13,76 & 0 & 124,78 & 950,30 & 0 & 950,30 & 15,84 & 15,84 & $\mathrm{CHF}$ \\
\hline
\end{tabular}

Figure 15. The transportation charge along the route of Gardebani station (exp.) - the port of Poti, the Republic of Georgia, the Swiss franc.

\subsection{Determination of Freight Charge According to the Method with a Tariff Fracture on Sea Transportation (Ukraine)}

The $16^{\text {th }}$ picture shows a scheme of the sea route along the Black Sea, from the port of Poti (Georgia) to the port of Odessa (Ukraine). The distance of the route is $1040 \mathrm{~km}$. 


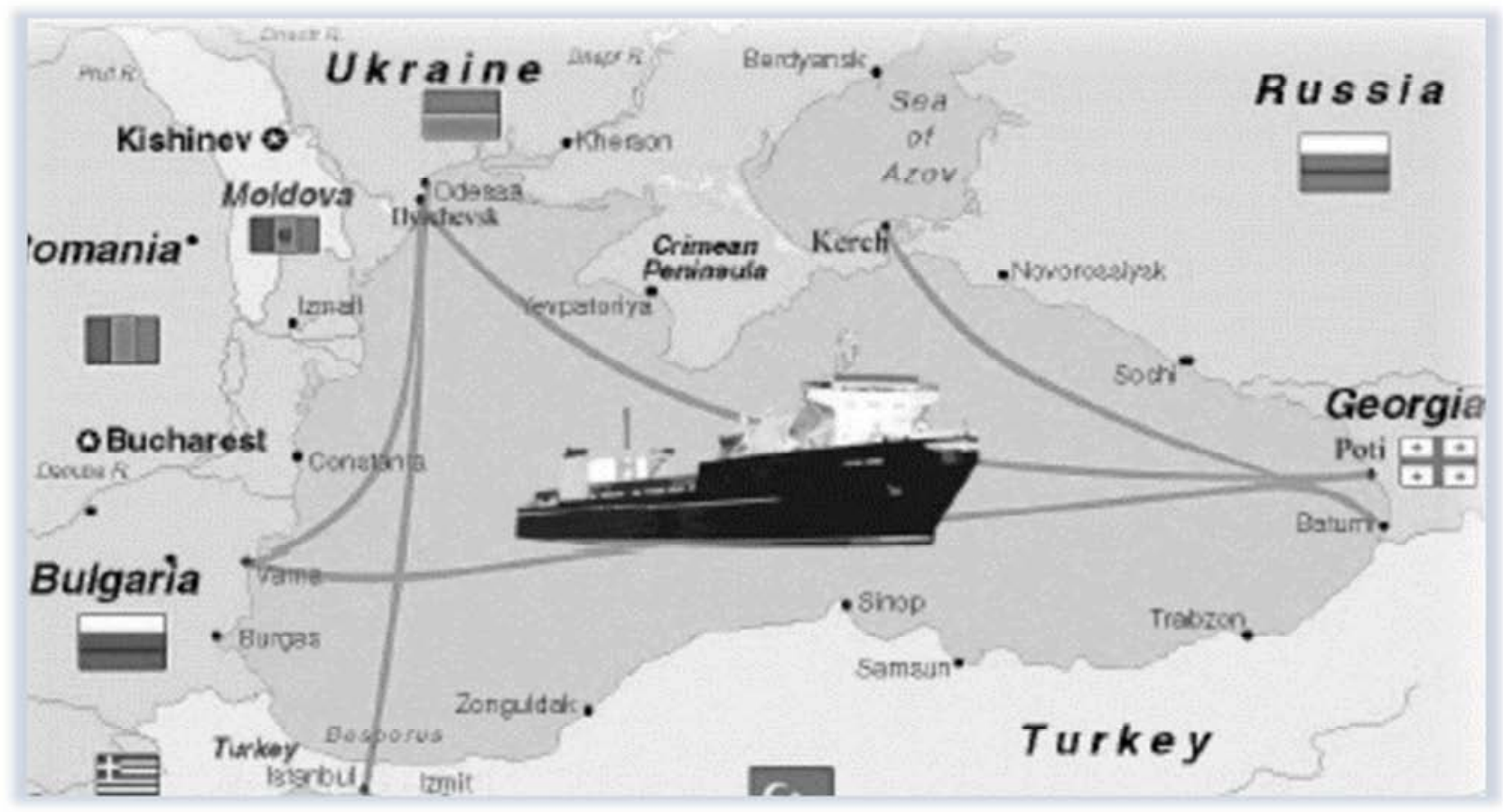

Figure 16. The sea route between the port of Poti (Georgia) and the port of Odessa (Ukraine).

The route of the freight train on the railways of Ukraine follows from Odessa station to Yagodin station (Figure 17). The tariff distance by rail of the Republic of Ukraine is $932 \mathrm{~km}$. Freight charge is defined in national currency, hryvnia and supranational currency, Swiss franc (Figures 18, 19).

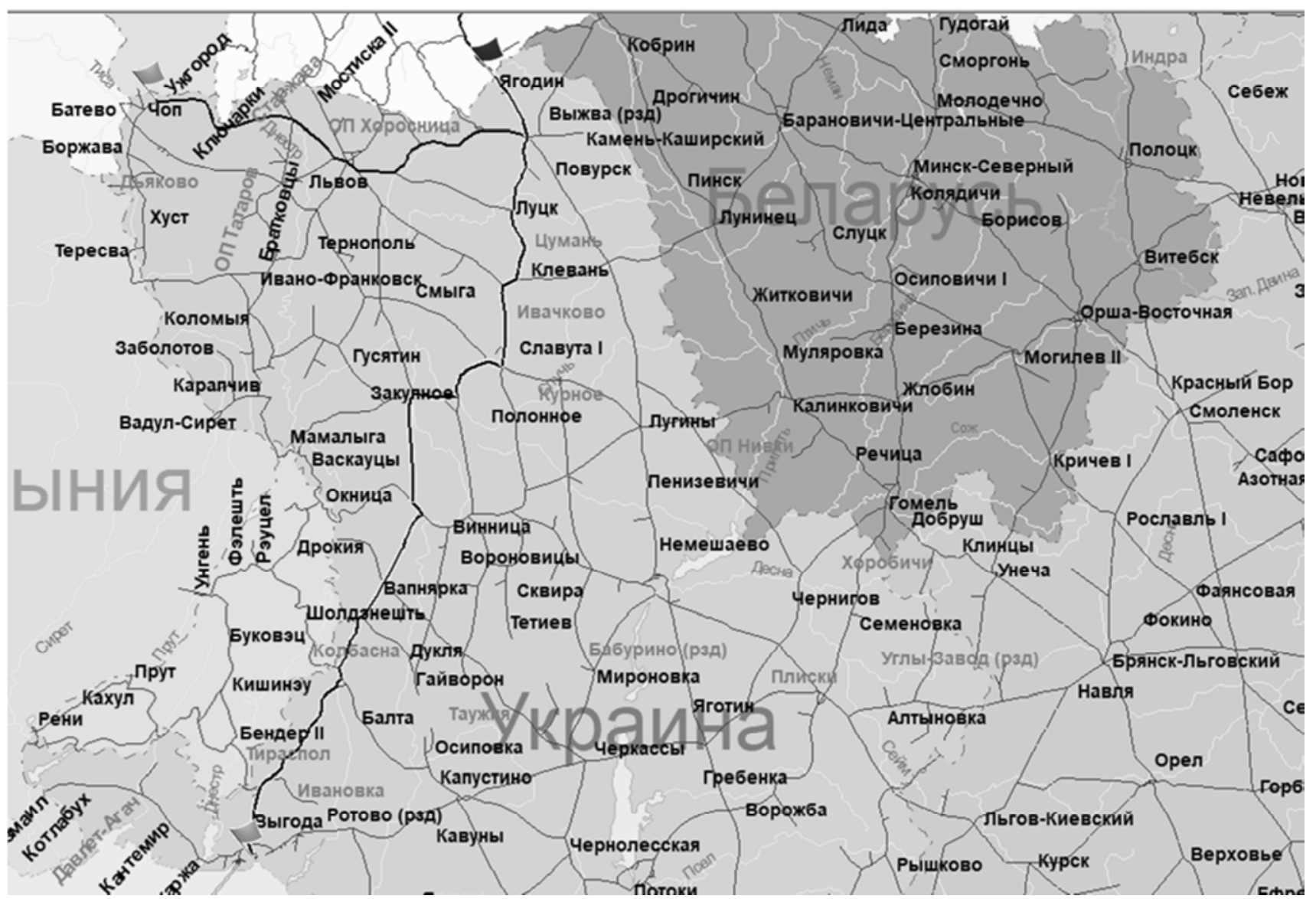

Figure 17. The route by rail of the Republic of Ukraine, st. Odessa - st. Yagodin. 


\begin{tabular}{|c|c|c|c|c|c|c|c|c|c|c|c|c|c|}
\hline Страна & Hanp. & Расстояние & вид & Пров. пл. & \begin{tabular}{|c|} 
за 1т \\
Пров. пл.
\end{tabular} & Охрана & Дon.c6оры & $\begin{array}{c}\text { Итого } \\
\text { 6ез НДC }\end{array}$ & НАC & Итoro & $\begin{array}{c}\text { 3a } 1 \mathrm{~T} \\
(6 \mathrm{ez} \mathrm{H} A \mathrm{C})\end{array}$ & за $1 \mathrm{~T}$ & Валюта \\
\hline \multirow{2}{*}{ Украина } & $\Rightarrow$ & 932 & TP y3 & 15326,00 & 255,43 & 口 & 1020,20 & 16346,20 & 0 & 16346,20 & 272,44 & 272,44 & UAH $\vee$ \\
\hline & $\leftarrow$ & 932 & TP y3 & 3757,70 & 0 & 0 & 970,10 & 4727,80 & 0 & 4727,80 & 0 & 0 & UAH $\checkmark$ \\
\hline \multirow[t]{2}{*}{ Utoro } & & 1864 & & 19083,70 & 318,06 & 0 & 1990,30 & 21074,00 & 0 & 21074,00 & 351,23 & 351,23 & UAH \\
\hline & & 1864 & & 19083,70 & 318,06 & 0 & 1990,30 & 21074,00 & 0 & 21074,00 & 351,23 & 351,23 & UAH \\
\hline
\end{tabular}

Figure 18. The transportation charge on the route Odessa - Yagodin, hryvnia.

The freight charge by the railway of Ukraine is 21074 UAH (Ukrainian currency, UAH).

\begin{tabular}{|c|c|c|c|c|c|c|c|c|c|c|c|c|c|}
\hline Страна & Hanp. & Расстояние & вид & Пров. пл. & \begin{tabular}{|c|} 
за 1т \\
Пров. пл.
\end{tabular} & Охрана & Aоn.c6оры & $\begin{array}{c}\text { Итого } \\
\text { 6ез НДC }\end{array}$ & $\mathrm{HAC}$ & Utoro & $\begin{array}{c}\text { за } 1 \mathrm{~T} \\
\text { (6ез HAC) }\end{array}$ & 3a $1 \mathrm{t}$ & Валюта \\
\hline \multirow{2}{*}{ Украина } & $\Rightarrow$ & 932 & TP Y3 & 565,47 & 9,42 & 口 & 37,64 & 603,11 & 의 & 603,11 & 10,05 & 10,05 & $\mathrm{CHF}$ \\
\hline & $\leftarrow$ & 9 & TP Y3 & 138,64 & 0 & 0 & 35,79 & 174,43 & 0 & 174,43 & 0 & 0 & $\mathrm{CHF} \vee$ \\
\hline \multirow[t]{2}{*}{ Итого } & & 1864 & & 704,11 & 11,74 & 0 & 73,43 & 777,54 & 0 & 777,54 & 12,96 & 12,96 & CHF \\
\hline & & 1864 & & 704,11 & 11,74 & 0 & 73,43 & 777.54 & 0 & 777.54 & 12,96 & 12,96 & CHF \\
\hline
\end{tabular}

Figure 19. The transportation charge along the route st. Odessa - st. Yagodin, Swiss franc.

\section{Determine the Payment by Method on the Through-shoulder Technique}

The freight charge for the transportation of grain in a specialized rolling stock by rail of Ukraine is $777,54 C h F$. The transportation fee is indicated for the unit of rolling stock, i.e. for one grain carrier.

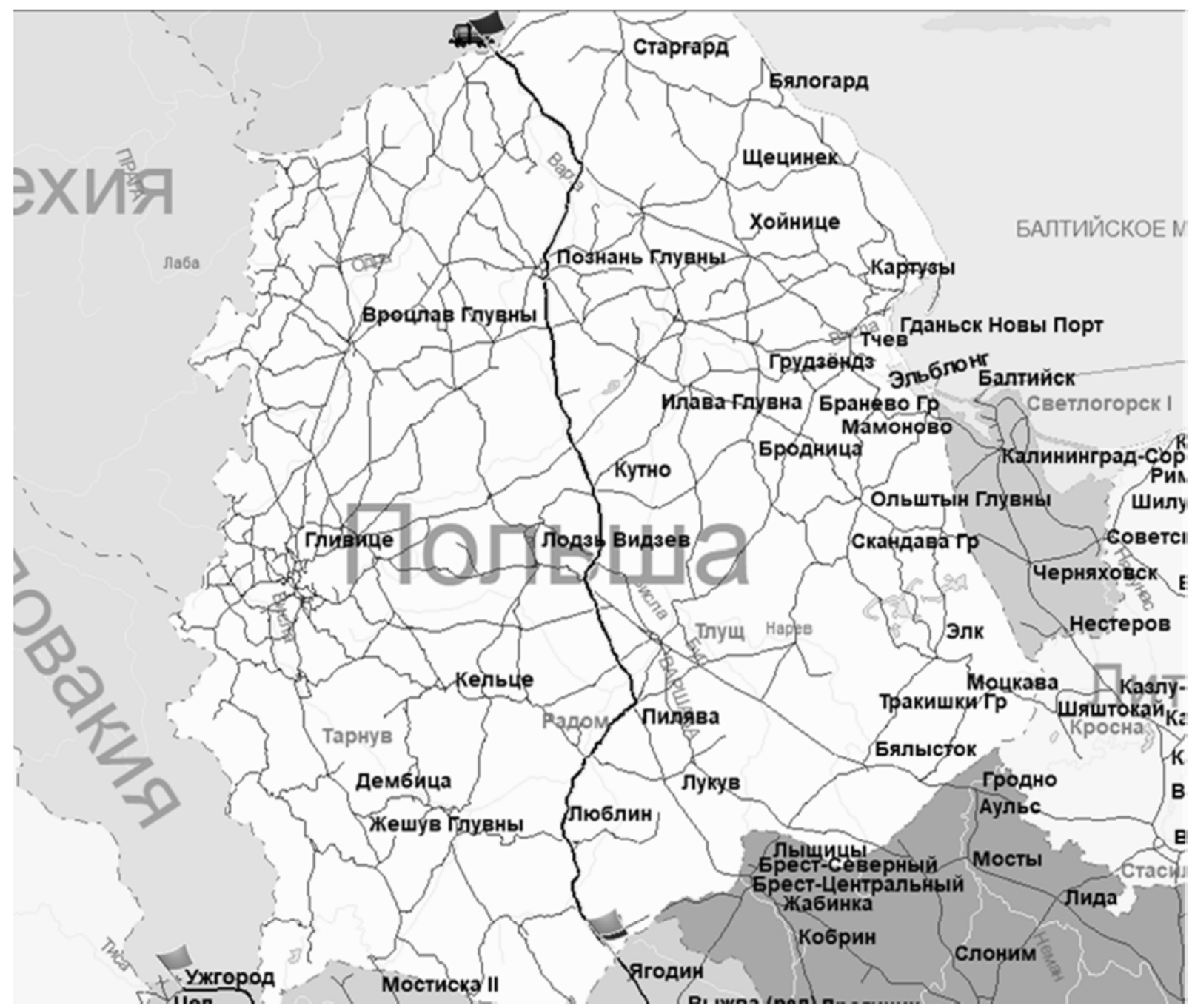

Figure 20. The route of the Poland's railways, st. Dorohusk - st. Kostrzyn (exp.). 
Tariff distance between the st. Dorohusk (PKP) to the st. Kostrzyn is $744 \mathrm{~km}$. Kostrzyn station is on the border with Germany. The transportation charge on the route st. Dorohusk (PKP) - st. Kostrzyn (exp.), Poland is determined by the method of the Single Transit Tariff (STT) (figure 20). The essence of this technique lies in the fact that according to the tariff distance $(744 \mathrm{~km}), 2$ tariff class of the cargo being transported, we determine the specific tariff rate for 1 ton of transported cargo. In this case, the specific tariff rate is 17,10
$C h F$. To determine the freight charge for the wagon rate, you need to multiply the specific tariff rate by the weight of the cargo in the grain carrier (Table 1):

$$
17,10 * 60,0=1026,0 C h F
$$

where, 17,1- payment for 1 ton in Swiss francs ( 2 class); 60,0carrying capacity.

Table 1. Unit tariff rates according to the Unified Transit Tariff methodology.

\begin{tabular}{|c|c|c|c|c|}
\hline Distance in $\mathbf{k m}$ & Payme & viss francs & Axis fee in Swiss francs & Distance in $\mathbf{k m}$ \\
\hline \multirow[b]{2}{*}{$505-754$} & classes & & & \multirow[b]{2}{*}{$505-574$} \\
\hline & 1 & 2 & 3 & \\
\hline $705-714$ & 32,70 & 16,50 & 35,06 & $705-714$ \\
\hline $715-724$ & 33,30 & 16,70 & 35,55 & $715-724$ \\
\hline $725-734$ & 33,60 & 17,00 & 36,03 & $725-734$ \\
\hline $735-744$ & 34,20 & 17,10 & 36,53 & $735-744$ \\
\hline $745-754$ & 34,70 & 17,40 & 37,02 & $745-754$ \\
\hline
\end{tabular}

\section{The Compare Methods on the Tariff break and Through-shoulder Technique}

The results of freight charges calculations by railways of the countries participating in the railway communication will be summarized in tabular form (Tables 2, 4).

Table 2. Determination of the freight charge according to the scheme with a tariff fracture.

\begin{tabular}{|c|c|c|c|c|}
\hline № II/II & Destination stations & Tariff distance, $\mathrm{km}$ & The freight charge & \\
\hline 1 & st. Astana- st. Dina Nurpeisova, Kazakhstan & 2122,0 & $294692,18 T g$ & $864,87 \mathrm{ChF}$ \\
\hline 2 & st. Kigash - st. Samur, Russia & 748,0 & $114013,37 R R$ & $1846,82 \mathrm{ChF}$ \\
\hline 3 & st. Yalama (exp.), - Boyuk-Kesik (exp.), Azerbaijan & 680,0 & $3072,68 A Z N$ & $1735,16 C h F$ \\
\hline 4 & st. Gardabani (exp.) - the port of Poti, Georgia & 360,0 & $989,90 \$$ & $950,30 \mathrm{ChF}$ \\
\hline 5 & Port of Poti (Georgia) - Port of Odessa (Ukraine) & 1040,0 & - & $685,0 \mathrm{ChF}$ \\
\hline 6 & st. Odessa - st. Yagodin, Ukraine & 932,0 & 21074,0 UAH & $775,54 C h F$ \\
\hline \multirow[t]{4}{*}{7} & st. Dorohusk (PKP) - st. Kostrzyn (exp.), Poland & 744,0 & $1026,0 \mathrm{ChF}$ & $1026,0 \mathrm{ChF}$ \\
\hline & The length of the intermodal route & $6626,0 \mathrm{kM}$ & - & $7198,69 \mathrm{ChF}$ \\
\hline & The length of sea route & $1040,0 \kappa \mathrm{k}$ & - & $685,0 \mathrm{ChF}$ \\
\hline & The length of multimodal route & $7666,0 \mathrm{kM}$ & - & $7883,69 C h F$ \\
\hline
\end{tabular}

The transportation charge according to the door-to-door haul scheme, the route st. Astana (Kazakhstan) - st. Kostrzyn (Poland) is determined by the method of the Single Transit Tariff (STT). The essence of this technique is that the tariff distance $(6626.0 \mathrm{~km}), 2$ tariff class of the cargo being transported, we determine the tariff rate for 1 ton of cargo transported. In this case, the specific tariff rate is $154.40 \mathrm{ChF}$. To determine the freight charge for the wagon rate, you need to multiply the specific tariff rate by the weight of the cargo in the grain carrier, then (Table 3):

$$
154,40 * 60,0=9264,0 C h F
$$

where, 154,40-payment for 1 ton in Swiss francs (2class); 60,0 - carrying capacity.

Table 3. Unit tariff rates according to the Unified Transit Tariff methodology.

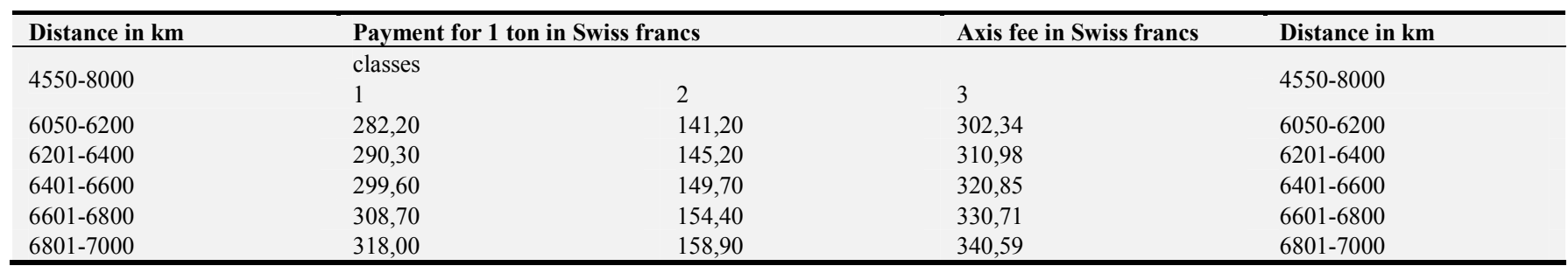


Table 4. Comparison of the freight charges on the route st. Astana - st. Kostrzyn, ChF.

\begin{tabular}{|c|c|c|c|c|}
\hline \multirow[b]{2}{*}{ № II/II } & \multirow[b]{2}{*}{ Destination stations } & \multirow[b]{2}{*}{ Tariff distance, $\mathbf{k m}$} & \multicolumn{2}{|l|}{ Freight charge, $\mathrm{ChF}$} \\
\hline & & & $\begin{array}{l}\text { according to the scheme } \\
\text { with a tariff fracture }\end{array}$ & $\begin{array}{l}\text { the door-to door haul } \\
\text { scheme }\end{array}$ \\
\hline 1 & st. Astana- st. Dina Nurpeisova, Kazakhstan & 2122,0 & 864,87 & - \\
\hline 2 & st. Kigash - st. Samur, Russia & 748,0 & 1846,82 & - \\
\hline 3 & st. Yalama (exp.), - Boyuk-Kesik (exp.), Azerbaijan & 680,0 & 1735,16 & - \\
\hline 4 & st. Gardabani (exp.) - the port of Poti, Georgia & 360,0 & 950,30 & - \\
\hline 5 & Port of Poti (Georgia) - Port of Odessa (Ukraine) & 1040,0 & 685,0 & \\
\hline 7 & st. Dorohusk (PKP) - st. Kostrzyn (exp.), Poland & 744,0 & 1026,0 & - \\
\hline \multirow[t]{4}{*}{8} & Astana-st. Kostrzyn, the door-to- door haul scheme & & - & - \\
\hline & The length of the intermodal route & $6626,0 \mathrm{~km}$ & $7198,69 \mathrm{ChF}$ & 9264,0 ChF \\
\hline & The length of sea route & $1040,0 \mathrm{~km}$ & $685,0 \mathrm{ChF}$ & $685,0 \mathrm{ChF}$ \\
\hline & The length of multimodal route & $7666,0 \mathrm{~km}$ & 7883,69 ChF & 9949,0 ChF \\
\hline
\end{tabular}

\section{Conclusion}

Income to the budget when using the technique of the door-to- door haul scheme is $2065,31 \mathrm{ChF}$. Let's present the obtained data of the freight charge in the supranational currency EuroNur. The exchange rate of a supranational currency is equal to the euro. At the moment, the ratio between the Swiss franc and the euro is $1 C h F=0,87 E U R$ (Table 3). The course of the supranational currency $€^{N}$ is chosen equal to the rate of the European currency EuroNur. Then we get the following results (Table 5).

Table 5. Comparison of the freight charges along the route st. Astana - the port of Poti, $\epsilon^{N}$.

\begin{tabular}{|c|c|c|c|c|}
\hline \multirow[b]{2}{*}{ № п/II } & \multirow[b]{2}{*}{ Destination stations } & \multirow[b]{2}{*}{ Tariff distance, $\mathbf{k m}$} & \multicolumn{2}{|l|}{ Freight charge, $\epsilon^{N}$} \\
\hline & & & $\begin{array}{l}\text { according to the scheme } \\
\text { with a tariff fracture }\end{array}$ & $\begin{array}{l}\text { the door-to door } \\
\text { haul scheme }\end{array}$ \\
\hline 1 & st. Astana- st. Dina Nurpeisova, Kazakhstan & 2122,0 & 752,4369 & - \\
\hline 2 & st. Kigash - st. Samur, Russia & 748,0 & 1606,733 & - \\
\hline 3 & st. Yalama (exp.), - Boyuk-Kesik (exp.), Azerbaijan & 680,0 & 1509,589 & - \\
\hline 4 & st. Gardabani (exp.) - the port of Poti, Georgia & 360,0 & 826,761 & - \\
\hline 5 & Port of Poti (Georgia) - Port of Odessa (Ukraine) & 1040,0 & 595,95 & \\
\hline 7 & st. Dorohusk (PKP) - st. Kosrtzyn (exp.), Poland & 744,0 & 1026,0 & - \\
\hline \multirow[t]{4}{*}{8} & Astana-st. Kostrzyn, the door-to- door haul scheme & & - & - \\
\hline & The length of the intermodal route & $6626,0 \mathrm{~km}$ & 6262,86 & 8059,68 \\
\hline & The length of sea route & $1040,0 \mathrm{~km}$ & 595,95 & 595,95 \\
\hline & The length of multimodal route & $7666,0 \mathrm{~km}$ & 6858,81 & 8655,63 \\
\hline
\end{tabular}

The economic effect of the introduction of the door-to- door haul technique in determining the freight charges along the route st. The port of Poti will cost $1796,82 \epsilon^{N}$ per wagon (wheat). The indicated route is laid on the railways of the countries of the participants (Republic of Kazakhstan, Russian Federation, Republic of Azerbaijan, Republic of Georgia) of intermodal communication. In the port of Poti, cargo is reloaded to sea transport with the assignment to the port of Odessa (Ukraine), as well as the ports of Bulgaria, Romania. In terms of one million tons of cargo transported it will be:

$16666,667 * 2065,31=34421819,564 C h F$

$16666,667 * 1796,82=29946988,021 €^{N}$

\section{References}

[1] Zh. M. Kuanyshbayev. Supranational currency EvroNur (EvroNur). Certificate of state registration of rights to the object of copyright. The entry in the register No. 1928 of November 12, 2014.

[2] Zh. M. Kuanyshbayev, M. I. Arpabekov. Logistics in transport.
Monograph. Palmarium Academic Publishing is a trademark of: LAP LAMBERT Academic Publishing GmbH \& Co. KG. Heinrich - Bocking -Str. 6-8, 66121 Saarbrucken, Germany, 2015. 247 р. Тираж - 100 экз.

[3] Zh. M. Kuanyshbayev, M. I. Arpabekov, M. B. Temirbolatova Designing logistic schemes for the transport of ferrochromium along the route Zh. Zholkuduk - st. Amsterdam. Certificate of state registration of rights to the object of copyright. The entry in the register No. 1679 of July 10, 2017.

[4] Zh. M. Kuanyshbayev, Zh. B. Sermuhanov Designing of logistical schemes on the route of Aksu station (KTZh) - art. Lianyungang (PRC). Certificate of state registration of rights to the object of copyright. The entry in the register No. 1680 of July 10, 2017.

[5] Zh. M. Kuanyshbayev, D. K. Alimsurova. Formation of the Black Sea transport corridor (Pavlodar - Poti). Certificate of state registration of rights to the object of copyright. The entry in the register №0041 from February 15, 2018.

[6] Zh. M. Kuanyshbayev, M. I. Arrpabekov. Projection of Logistic Schemes in Intermodal Communications. Journal of Applied Economic Sciences, Romanya, Volume XII, Winter, 2018, №4, Scopus, IF=0.655, p. 112-128. ISSN-L 1843-6110. ISSN 2393-5162. 
[7] Zh. M. Kuanyshbayev. Logistics of the pass-through route from st. Astana to st. Muuga. Science and world, international scientific journal, № 8 (60), 2018, WOS, IF=0,325. P. 39-45.

[8] Zh. M. Kuanyshbayev, A. Aukeshova. Definition of the freight according the scheme with the tariff change and thouch shoulder. Science and world, international scientific journal: Volgograd № 3 (19), 2015.- Р. 44-50. (0,37п. л.). WOS, IF $=0,326$ Global impact Factor 2013, Australia.

[9] Zh. M. Kuanyshbayev, T. Б. Suleimenov, E. S. Eshimbay. Designing of logistic schemes for the carriage of goods on railway transport (st. N. Tagil-st. Zhezkazgan). Science and world, international scientific journal: Volgograd No. 3 (19), 2015.-P. 50-55. (0.31 p. p.). WOS, $\mathrm{IF}=0.326$ Global impact Factor 2013, Australia.

[10] Zh. M. Kuanyshbayev, M. I. Arpabekov. The engineering of logistic schemes in transportation of metal products. Ecology, environment and conservation, Ref. No. EEC - F- 125. $\mathrm{SJR}=0.103$.

[11] Zh. M. Kuanyshbayev, N. K. Aidikenova, A. D. Kasymzhanov. Certificate of state registration of rights to an object of copyright entitled "Packaging material for the transport of petroleum products", as. Issued by the Committee on Intellectual Property Rights of the Ministry of Justice of the Republic of Kazakhstan. The entry in the register for No. 1668 of December 13, 2013 - 5c. 0.3 p. p.

[12] Kuanyshbaev Zh. M., Arpabekov M. I. Using EuroNur at formation of middle-east transportation corridor. Science and world, international scientific journal, 2016. № 12 (40). Vol. I, WOS, IF=0,325. P. 45-55.
[13] Zh. M. Kuanyshbayev. Using supranational currency. at formation of pacific transportation corridor. Science and world, international scientific journal, 2016. № 12 (40). Vol. I, WOS, $\mathrm{IF}=0,325$. P. 55-61.

[14] Zh. M. Kuanyshbayev, N. K. Aidikenova, I. M. Zhanatov A certificate of state registration of rights to an object of copyright, entitled "Methodology for determining the freight charges for railway transport," avt. Certificate. Issued by the Intellectual Property Rights Committee of the Ministry of Justice of the Republic of Kazakhstan. The entry in the register for No. 421 of 31.03. 2014g-12s. 0.75 pp.

[15] Unified Transit Tariff (with amendments and additions as of 01.01.2014). Official publication. OSZhD Committee, Warsaw. $99 \mathrm{p}$.

[16] Zh. M. Kuanyshbayev, S. N. Nurakov. Logistic scheme of grain transportation on route the Astana station - the Poti statio. Science and world, international scientific journal, № 5 (57), 2018, Vol. I, WOS, IF=0,325. P. 33-39.

[17] Zh. M. Kuanyshbayev. The use of cryptocurrency PEERCOIN (PPC) on the route of st. Aksu (Kazakhstan Railways) - port of Lianyungang (China). Science and world, international scientific journal, № 12 (64), 2018, Vol. I, WOS, IF=0,325. P. 59-64.

[18] International Transit Tariff. (with comparisons and additions as of 01/01/2014). Official publication. OSZhD Committee, Warsaw. 123p. 